\title{
Integration of High Order Thinking Skills in Research Method Subject in University
}

\author{
Syamsul Arif ${ }^{1}$, Basyaruddin $^{2}$, Achmad Yuhdi $^{3}$ \\ 1,2,3Universitas Negeri Medan, Indonesia \\ Email: syamsulariefsiregar@gmail.com
}

\begin{abstract}
High Order Thinking Skills is the ability to connect, manipulate, and change the knowledge and experience that is owned critically and creatively in determining decisions to solve problems in new situations. In the 21st century or the Industrial Revolution 4.0 era, the learning model continues to change as a form of adjustment to the demands of the development of science and technology. The learning model that used to be still conservative in the auspices of LOTS (Low Order Thinking Skill) with the teacher / lecturer as the center of learning switched to the HOTS (High Order Thinking Skill) model by relying on reasoning, innovation and creativity to solve problems. So, the students become the center of learning. This study aims to design the shape of the HOTS learning model in the Research Methods subject. The prototype of the learning model is developed to be five steps / stages of learning, namely: (1) identifying problems based on observations of learning activities in schools, (2) selecting problems to study, (3) gathering information about the problems to be studied, (4) developing proposals, (5)presentation of proposals. The results of the study showed that the learning process of the Research Methods subject by applying the HOTS-based learning model would lead the students to form a critical attitude, increase independence and gain a lot of experience that are useful to compile scientific works including the completion of thesis preparation.
\end{abstract}

Keywords: high orders thinking skills; research methods; university

\section{Introduction}

As one of the universities that synergizes with the development, State University of Medan (Unimed) has been implemented HOTS-based learning in the form of implementing the 6 tasks-based KKNI curriculum that was socialized since 2016 to all departments to be implemented, including the Indonesian Language and Literature department. Conceptually, the HOTS-based learning approach has been included in 6 student assignments. The six tasks are: 1) routine tasks, 2) critical journal review, 3) critical book review, 4) mini research, 5) generating ideas project and 6) projects.

Each explanation of the six types of tasks include: Routine assignments, critical journal reviews and critical book reviews are the implementation of student investigations in structuring criticism. Mini research, generating ideas project and projects are an implementation of ideas to foster problem solving abilities and creative innovation. Even so, HOTS has not been internalized well in its scope and guidance, especially in the thesis discussion. In the thesis preparation process, many students simply refer to, and even quote the theories and methods of the previous thesis. This will result in a monotonous application of theory and research methods without the values of innovation and creation that should have of every student consciously.

Creativity in preparing thesis is not only being influenced by deepening in theoretical subjects, but also being influenced by methodological deepening in research methods subject. In the research method subject, it is familiar for the students to mere focus on methods that are often used. This makes the research feel bland, because the flow of criticism is blocked and creativity is only based on the previous thesis. There needs to be a breakthrough in the research 
method lecture hall. The purpose of national education is so noble, because with the achievement of these goals, all social problems can be overcome including students as the next generation of the nation. Physical education, sports and health is one of the entry points, because it develops; physical fitness, movement skills, critical thinking, social, reasoning, emotional stability, moral actions, aspects of a healthy lifestyle and the introduction of a clean environment through physical activities can be formed by young people who have quality human resources (Pandaleke, 2019). HOTS which promotes synthesis and innovation in learning can be one of the solutions to improve the quality of learning in research methods based on digital technology or e-learning.

Theoretically, High Order Thinking Skills (HOTS) explained by Saputra (2016) is a process of thinking in a higher level of knowledge developed from various cognitive concepts and methods and learning taxonomies, such as bloom taxonomy. Furthermore, Widodo (2013) asserted that by implementing high order thinking students / students will be able to solve problems, be able to construct explanations, be able to do hypotheses and understand complex things more clearly. 'The main purpose of high order thinking skills is how to improve students' thinking skills at a higher level, especially those related to the ability to think critically in receiving various types of information, think creatively in solving a problem using knowledge possessed and make decisions in situations complex situations (Saputra, 2016: 91-92). The ability to think critically consists of the dimensions of the process of analyzing and evaluating, the ability to think creatively consists of the dimensions of the creating process. The ability to think critically and creatively is used to set decisions and solve problems in new situations (Imelda, 2019).

The concept of high order thinking skills is adapted from the cognitive level expressed in bloom's taxonomy. At least, there are three concepts of the bloom level that require students to think at a higher level. These three concepts are the basis of high order thinking skills, which refer to the activity of analyzing, evaluating, and creating knowledge that is adjusted according to conceptual, procedural and metacognitive. According to Krathwohl (2002) in A revision of Bloom's Taxonomy, states that indicators to measure high order thinking skills include analyzing (C4), namely the ability to separate concepts into several components and connect with each other to gain an understanding of the concept as a whole, evaluate (C5) that is the ability to determine the degree of something based on certain norms, criteria or standards, and create (C6), that is, the ability to combine elements into something new, complete and broad, or make something original.

The implementation of this research and development will further integrate the highorder thinking skills mentioned above in the research method subject in the Indonesian Language and Literature Education Study Program, Unimed. In addition, there are several factors that require the teaching of research methods in tertiary institutions. The first, the need for students' ability to apply theories of learning received in college on social life through a study called the preparation of scientific papers (thesis). The second is to familiarize students as an intellectual group to think about acting and issue opinions through scientific studies so they could achieve objective scientific degrees. Third, in compiling scientific papers, students can convey with a clear method and there are certain procedures that are considered objective and the procedures for delivering them correctly in accordance with their respective disciplines. Fourth, students can prove something that is doubtful in order to obtain knowledge that they think is new.

Research method is one of the determining subjects that can build students' scientific thinking skills. For students the activity of preparing a thesis is one of the obstacles in achieving their bachelor's degree. This is because students do not understand correctly and master the material of research methods. The lack of mastery of research methods can also be caused by inappropriate learning implemented by lecturers in teaching subject matter in Research Methods. 
The more fatal consequence of this situation is that students have great difficulty in preparing their thesis because to prepare their thesis must be carried out with integrated and systematic steps called the Research Methods (Arikunto: 2007).

The research method is one of the core subjects given by universities to students by means of a student learning about the attitudes and behavior of researchers, so that those concerned have ethics in conducting research. In any case, students are able to formulate appropriate research strategies so that the objectives to be achieved can be successful. Therefore, out come from the Research Method for students is concerned with knowledge of how to conduct proper research, students' attitudes and behavior in conducting research that is upholding scientific ethics such as not manipulating data, so that they are born from the campus of scientific human figures in thinking, issuing opinions and compile scientific works of knowledge, which in turn can provide quality human resources.

The focus of discussion on this scientific work is the application of learning method. Research in this context must have an active lecturer to apply the most appropriate method so that the learning process can achieve the objectives as mandated by the curriculum. After taking the Research Method subject students are expected to be able to arrange their thesis properly. Based on the description above, it can be said that the lecturers must be able to design as well as apply the Research Method learning method, so it could produce many students who think critically and critically and act scientifically in preparing scientific works including the preparation of the thesis.

During this time, the lecturers are often less responsive about what is conveyed in class with social realities in the community / conditions of teaching Indonesian in very different schools. The implementation of evaluation of learning outcomes plays an important role in motivating and learning achievement of students. Therefore, every teaching and learning process must be carried out in the evaluation activities, to see how the progress that has been achieved by students and how effective the teaching is done by the teacher in the class (Ananda, 2019). This is because the learning process is only focused on one dimension only, namely cognitive. Two other important dimensions are not getting enough attention, so students don't get a picture of phenomena in the community. Moreover in the subject of research methods, the phenomenon of community life / teaching conditions in schools is absolutely necessary so that students get a concrete picture. However, if the lecturers are consistently grounded in the three domains of education, namely knowledge, attitudes and skills, the learning outcomes produced are realistic and responsive learning. In this context universities have not been able to transform education as what is referred to by Paulo Piere as the "Awareness Process" (Rosyada, 2003).

Based on those reasons, the researcher conduct a research activities development of the HOTS learning model in the research method subject. The section in this article is the design of the HOTS learning model in question.

\section{Research Method}

This research is part of the development research activities carried out in AugustNovember 2019 at the Indonesian Language and Literature Education Study Program, State University of Medan. This activity is the second stage of a research development carried out to produce a HOTS-oriented learning model in tertiary institutions, especially in research method subject. Prior research has been carried out in the form of distributing questionnaires to see the level of needs of the academic community, especially students of HOTS-oriented learning models 
in research method subjects. In this case, the sample was chosen purposively with 95 students who are in fifth semester and took part in research method subject of the 2019-2020 study year.

\section{Discussion}

\section{Application of Research Method Subject According to HOTS Model}

In applying the HOTS learning model to the Research Method subject, a lecturer must create the right strategy so that students are motivated to learn. The learning process in the HOTS learning model developed in this study refers to the problem-based learning approach and the ability to solve problems / cases. The prototype of the learning model developed includes five steps / stages of learning, namely: (1) identifying problems based on observations of learning activities in schools, (2) selecting problems to be studied, (3) gathering information about the problems to be studied, (4) developing proposal, (5) presentation of the proposal. The application of the learning steps in the Research Methods subject is described as follows:

\section{a. Identify Problem}

In order to identify the problem more accurately and comprehensively, the lecturer needs to form a study group in which the number of students in each group ranges from 3-5. Each group observes the learning activities carried out at school. Observations include interviews with teachers related to the preparation of teaching like Learning Implementation Plan (RPP), observing the learning process, and interviews related to the assessment process conducted by the teacher. This activity lasts for 3 weeks. In detail student observations will be reported based on the following observation aspects.

Table 1. Observation Aspects of Problem Identification in School Observation Activities

\begin{tabular}{|c|c|c|}
\hline No & Aspects Observed & Description of Observation Results \\
\hline A & Learning Media & $\ldots$ \\
\hline & 1. 2013 curriculum & (n.w. \\
\hline & 2. Syllabus & $\ldots \ldots \ldots \ldots \ldots \ldots \ldots \ldots \ldots \ldots \ldots \ldots \ldots$ \\
\hline & 3. Learning Implementation Plan (RPP) & 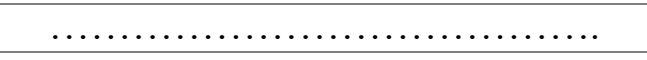 \\
\hline B & Learning Process & (n.w. \\
\hline & 1. Introduction & 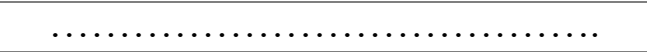 \\
\hline & 2. Presentation of Material & 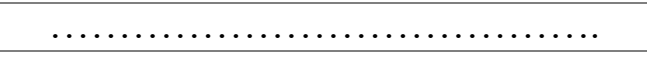 \\
\hline & 3. Learning Method & 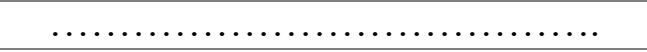 \\
\hline & 4. Use of Language & 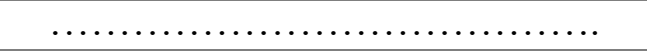 \\
\hline & 5. Use of time & 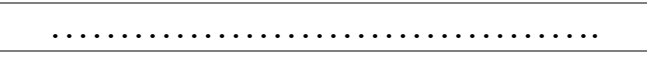 \\
\hline & 6. Move & 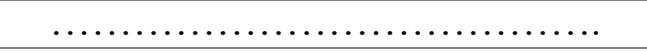 \\
\hline & 7. How to motivate students & 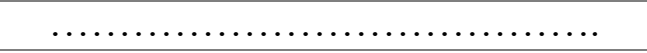 \\
\hline & 8. Questioning technique & 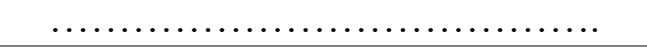 \\
\hline & 9. Class mastery technique & 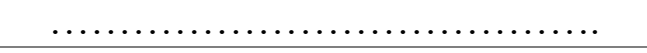 \\
\hline & 10. Use of media & n.w. \\
\hline & 11. Form and method of evaluation & 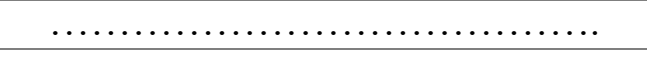 \\
\hline & 12. Closing & (n) \\
\hline C & Students' Behavior & 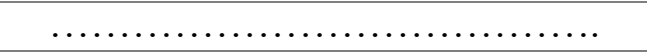 \\
\hline & 1. Students' behavior in the classroom & 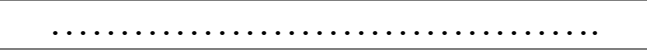 \\
\hline & 2. Students' behavior outside of classroom & 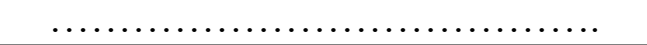 \\
\hline
\end{tabular}

Besides making observations based on the rubric, students must also prepare in advance the interview guidelines before they observe the school. Interview guidelines prepared are guidelines for interviewing teachers and students at the school to be visited. 


\section{b. Define Problem}

After each group collects the problem set, then the lecturer and students discuss which problem will be the topic of discussion. Obviously, one of the considerations is the problem most proposed by each group will be chosen as a presentation of the learning topic, for example the selected topic is a technique the preparation of the questionnaire (list of questions), then the topic of the preparation of questionnaires becomes the subject of inter-group discussion under the guidance and direction of the lecturer who teach the subject.

\section{c. Gathering Information about the Problem Being Assessed}

In this step, each group discusses to study material which if necessary needs to be discussed in more depth from the problems that have been determined as study material in the learning process, so that students receive a lot of information as a provision for conducting research. For example in the study of questionnaire preparation problems that are examined more in depth about the technique of determining the indicator of the questions given to respondents in order to obtain data / information that suits the needs of researchers, the consequence of this problem will be provided more free time in the learning process.

\section{d. Draft Proposal}

Research proposal is a detailed description of the process that will conduct by the researchers to be able to solve research problems. In general, a research proposal is a guideline that contains the steps that the researcher will follow to conduct the research. The preparation of proposals needs to be anticipated the emergence of various sources that can be useful so that it can be used in supporting research or factors that might restrict the research activities. The preparation of a research proposal is carried out for 3 weeks in the supervision and guidance of lecturers in the course.

\section{e. Present Proposal}

The research proposal presented by students is an improvement effort that can be done by the teacher in the learning process. It is based on the observation activities carried out at the beginning of learning activities. The improvement effort can be in the form of applying learning methods and models, or it can also be in the form of developing instructional media for teachers. In addition, the research topic can also be in the form of a description of the implementation of learning by the teacher.

Based on the sequence of learning steps in the HOTS learning model, it can be illustrated in the following diagram.

\begin{tabular}{|l|l|l|}
\hline Meeting 2: Presentation of interview guidelines & $\begin{array}{l}\text { Meeting 1: Introduction of a college contract and } \\
\mathrm{RPS}\end{array}$ \\
\hline Meeting 3, 4, 5: School observation & $\leftarrow \begin{array}{l}\text { Meeting 6,7, 9, 10: Preparation of research } \\
\text { proposals, if research data is still lack, it is possible } \\
\text { for students to return to school to collect research } \\
\text { data in the form of interview data and observation } \\
\text { results. }\end{array}$ \\
\hline
\end{tabular}

Figure 1. HOTS Oriented Learning Process Design in Research Methods Subject

The HOTS model of learning approach described above will provide motivation for students to develop more, because in practice students are required to be independent and creative in completing lecture material learning thoroughly, students' laziness when attending 
lectures will result in failure in mastering lecture material, which in turn will have great difficulty completing the final project that is preparing thesis.

\section{Conclusion}

The results of the study show that the learning process of Research Method by applying the HOTS-based learning model, will form a critical attitude, achieve much independent and acquire a lot of experience for students to compile scientific works including the completion of thesis preparation. Lecturers will provide more opportunities for students to develop themselves in the mastery of lecturing material taught.

\section{References}

Arikunto, Suharsini. 2007. Prosedure Penelitian Suatu Pendekatan Praktis. Jakarta: PT. Renika Cipta.

Ananda, R. (2019). Evaluation of Learning Outcome: Comparative Education Unit Level Curriculum with the 2013 Curriculum in MTsN 1 Medan. Britain International of Humanities and Social Sciences Journal, 1(1); 74-80.

Krathwohl, D. R. 2002. A revision of Bloom's taxonomy: An overview. Theory into practice 41(4), 212-218

Imelda and Anzelina, D. (2019). Students' Activities in Learning with Problem Based Learning Based Module to Enhance Students' HOTS on the Subject of Straight Line Equations. Budapest International Research in Linguistics and Education Sciences (BirLE) Journal, 2(4); 552-559.

Pandaleke, T., Dlis, F. and Widiastuti. (2019). The Effect of Balance, Arm Muscle Strength, and Creativity towards Discus skills on Faculty of Students of Manado State University Science. Britain International of Linguistics, Arts and Education Journal, 1(2): 160-174.

Rosyada, D, 2003, Menciptakan Experamental Democracy Melalui Pembelajaran, Warta PTM, Edisi (7) Tahun XV, 8-18.

Saputra, Hatta. 2016. Pengembangan Mutu Pendidikan Menuju Era Global: Penguatan Mutu Pembelajaran dengan Penerapan HOTS (High Order Thinking Skills). Bandung: SMILE's Publishing.

Widodo, T \& Kadarwati, S. 2013. High Order Thinking Berbasis Pemecahan Masalah Untuk Meningkatkan Hasil Belajar Berorientasi Pembentukan Karakter Siswa. Cakrawala Pendidikan 32(1), 161-171 